\title{
Bacterial infection in wheezy children.
}

1. MBBS, FCPS (Pediatric Medicine) Assistant Professor Pediatric Medicine

Nishtar University \& Hospital, Multan.

2. MBBS, FCPS (Paediatric Medicine) Associate Professor Paediatric Medicine

The Children's Hospital \& ICH Multan

3. MBBS, DCH, FCPS

Associate Profession Pediatric Endocrinology

The Children's Hospital \& the Institute of Child Health Multan.

4. MBBS, FCPS (Pediatric Medicine) Assistant Professor Pediatric Medicine

Nishtar University \& Hospital, Multan.

Correspondence Address:

Dr. Asim Khurshid

Department of Paediatric Medicine

The Children's Hospital \& ICH, Multan.

asimkhurshiddr@gmail.com

Article received on:

11/08/2020

Accepted for publication:

07/10/2020

\section{Maria Saleem ${ }^{1}$, Asim Khurshid ${ }^{2}$, Waqas Imran Khan ${ }^{3}$, Amna Wajdan ${ }^{4}$}

ABSTRACT... Objective: To determine the frequency of bacterial infection in children less than five years of age presenting with respiratory wheeze to Tertiary care centre. Study Design: Descriptive Case Series study. Setting: Department of Pediatrics, The Children's Hospital and The Institute of Child Health, Multan. Period: November 2019 to April 2020. Material \& Methods: A total of 130 children, presenting with respiratory symptoms were examined for presence of respiratory wheeze. After confirmation of chest auscultation, patients were enrolled. Information regarding duration of wheeze, axillary temperature, presence of chest in drawing and respiratory rate were recorded. Appropriate blood sample were drawn for total leukocyte count and differential leukocyte count from which absolute neutrophils count was calculated. Children were evaluated for the presence of bacterial infection as per operational definition. Results: There were $38(29.23 \%)$ female and $92(70.76 \%)$ male patients. Overall, mean age was $13.17 \pm 5.49$ with age range of $1-57$ months. Bacterial infection was noted in $33(25.38 \%)$ patients. Out of 130 patients presenting with wheeze, 50 patients $(38.46 \%)$ had temperature range of $98.1-99^{\circ} \mathrm{F}$. Absolute neutrophil count was more than $5000 / \mathrm{dl}$ in $42(32.30 \%)$ patients, out of these $33(78.6 \%)$ had bacterial infection. Chest X-rays were showing infiltrates in 110 (84.6\%) patients. Conclusion: Children suffering from wheeze have bacterial infection if age is less than five years and there is fever, crepitations, elevated absolute neutrophil count and radiographic evidence of pneumonia.

Key words: Bacterial Infection, Chext X-ray, Fever, Wheeze.

Article Citation: Saleem M, Khurshid A, Khan WI, Wajdan A. Bacterial infection in wheezy children. Professional Med J 2021; 28(2):176-180. https://doi.org/10.29309/TPMJ/2021.28.02.5250

\section{INTRODUCTION}

A wheeze is described as a musical and uninterrupted sound that initiates from oscillations in narrowed airways. Wheezing is commonly heard when children are breathing out, and these tiny airways collapse. ${ }^{1}$ Asthma, emphysema and chronic bronchitis are some of the commonest causes of wheezing during exhale. Wheezing during inhale is usually due to obstruction in the upper portion of respiratory tract. ${ }^{2}$

Around $50 \%$ of the infants are estimated to have minimum 1 episode of wheezing. ${ }^{3}$ Recurrent wheezing is a common occurrence as well, affecting around $1 / 3^{\text {rd }}$ of children of pre-school age. ${ }^{4}$ Majority of the children with recurrence of wheezing are noted to have asthma but causes other than asthma should also be evaluated in differential diagnosis. ${ }^{5}$
Among children, acute respiratory infection (ARI) is a common cause of hospital visits among children. ${ }^{6}$ In developing countries, ARls are also found to cause more than 4.5 million deaths in the pediatric age groups. ${ }^{7}$ Both bacterial as well as viral microorganisms are seen to be responsible for these deaths.

Local data has shown that wheezing was present in $40 \%$ of the children aged below 5 years who presented with fast breathing. ${ }^{8}$ International data has recorded a combined incident of wheezing as $18 \%, 24 \%$ and $43 \%$ by 7 years, 16 years and 33 years respectively. ${ }^{9}$ Pneumonia, hay fever and eczema were found to be independent linkage with incidence of wheezing in the childhood.

Among pre-school children, majority of wheeze are due to viral upper respiratory tract infections 
with high rate of recurrence. Data about wheezing and its impact on our healthcare system is missing but in UK, wheezing is estimated to consume $0.15 \%$ of the total healthcare budget. ${ }^{10}$ Despite high prevalence of wheezing among children, there is a lack of evidence regarding the frequency of bacterial infection in children aged less than 5 years. The problem of wheeze and especially associated with bacterial infection has been studied at global level adequately. But in Pakistan, a limited number of studies have been done. This study was designed to determine the frequency of bacterial infection in children less than five years of age presenting with respiratory wheeze to Tertiary care centre.

\section{MATERIAL \& METHODS}

This descriptive case series study was conducted at The Department of Pediatrics, The Children's Hospital and The Institute of Child Health, Multan, Pakistan from November 2019 to April 2020.

Approval from Institutional ethical committee was taken while informed consent was seeked from all the parents/guardians of the study participants.

Adopting non-probability purposive sampling, a total of 130 children aged less than 5 years and having respiratory wheeze of any duration and severity were enrolled. Respiratory wheeze in a child was defined as presence of ronchi audible on both sides of chest with a stethoscope which is agreed upon by two consultant pediatricians (having qualification of FCPS) after chest examination. Children having daily wheezing as described by the mother of the child, or children with gastro-esophageal reflux disease, with congenital heart disease, with any anatomic abnormalities of larynx and trachea or those having severe malnutrition (weight of child less than $60 \%$ of expected weight for that age) were excluded.

Children with respiratory symptoms presenting to Pediatrics Unit-II were examined for presence of respiratory wheeze. After their chest auscultation findings have been confirmed by two pediatricians, those children who satisfy the inclusion (on the basis of history, examination and appropriate investigations) were included in the study.

Name, age, gender and address were recorded as baseline characteristics. Duration of wheeze was recorded in days as given by parents/guardians of the child. Axillary temperature was recorded by thermometer every 4 hours for 24 hours. Presence of chest in drawing and respiratory rate of child at the time of inclusion in the study were noted to assess severity of disease. Age-specific criteria was used to define fast breathing. ${ }^{5}$ In age $<2$ months as $\geq 60$ breaths, $2-12$ months as $\geq 50$ breaths and in 12-60 months as $\geq 40$ breaths. 3 . Severity of wheeze was based on fast breathing and chest indrawing as if only fast breathing was present, was labeled as moderate disease whereas fast breathing and chest indrawing was labeled as severe disease.

Ascultatory findings (presence of crepitations) were recorded after being agreed upon by two consultants as described in operational definition. Appropriate blood sample were drawn and transported to laboratory for total leukocyte count and differential leukocyte count from which absolute neutrophils count were calculated. X-ray chest were obtained after sending the child to Institutional Radiology Department. X-ray was read and reported by consultant Radiologist of the institution with minimum experience of 5 years. Child was diagnosed to have bacterial infection as presence of all the following four parameters in the child: a. Fever (Recorded axillary temperature at any time during first 24 hours of admission more than 100 degree Fahrenheit). b. Presence of crepitations in any part of chest on auscultation with a stethoscope agreed upon by two consultant pediatricians (having qualification of FCPS) after chest examination. c. Blood examination by the hospital laboratory shows absolute neutrophil count of $>5000 /$ cubic millimeter. d. $X$ ray chest shows infiltrates in any part of the chest (as reported by radiologist).

Data was entered into SPSS version20. Proportion of children having bacterial infection was calculated by using the criteria as given in operational definition. Mean and standard deviation was calculated for numerical data 
including age, maximum recorded axillary temperature during first 24 hours after admissions and absolute neutrophil count. Frequencies were calculated for categorical data i.e. gender and address of the patient. Address were categorized according to district where the child was living as different districts have different frequency of bacterial infections. Stratification was done for severity of wheeze fever, neutrophil count and duration of wheeze (in days). Stratification was used to reduce control for effect modification. Presence of one or both of fast breathing and chest indrawing was used to assess severity of disease. Frequency of bacterial infection was described in total sample and in stratified groups. As it is a descriptive study no inferential statistics were drawn.

\section{RESULTS}

A total of 130 patients were included in the study. It included 38 (29.23\%) female patients and 92 $(70.76 \%)$ male patients with male to female ratio of 2.4:1. Mean age was13.17 \pm 5.49 months with age range of 1-57 months. Majority of the patients, $77(59.2 \%)$ were between 1-12 months of age, 32 (24.5\%) between 13-24 months of age, 12 (9.2\%) between 25-36 months, 6 (4.6\%) between 37-48 months and 3 (2.3\%) were between 49-60 months of age as shown in Table-l.

\begin{tabular}{|l|c|c|}
\hline Age (in months) & No. of Patients & Percentage (\%) \\
\hline $1-12$ & 77 & 59.2 \\
\hline $13-24$ & 32 & 24.6 \\
\hline $25-36$ & 12 & 9.2 \\
\hline $37-48$ & 6 & 4.6 \\
\hline $49---60$ & 3 & 2.3 \\
\hline \multicolumn{2}{|c|}{ Table-l. Age distribution of patients with wheeze } \\
(n=130) & Mean age \pm SD = 13.17 $\pm \mathbf{5 . 4 9}$ \\
\hline
\end{tabular}

There were 103 (79.2\%) children who were noted to have chest in-drawing, out of which, 77 (74.8\%) male and 30 (25.2\%) female. Frequency of bacterial infection in our series was seen in 33 $(25.38 \%)$ patients. Age distribution of children with bacterial infection is shown in Table-II.

Table-III shows distribution of gender among children with bacterial infection.

\begin{tabular}{|c|c|c|}
\hline $\begin{array}{l}\text { Age } \\
\text { (in months) }\end{array}$ & $\begin{array}{l}\text { No. of Patients with } \\
\text { Bacterial Infection }\end{array}$ & Percentage (\%) \\
\hline 1-----12 & 17 & 51.51 \\
\hline $13-24$ & 8 & 24.24 \\
\hline $25-36$ & 4 & 12.12 \\
\hline $37-48$ & 2 & 6.06 \\
\hline 49----60 & 2 & 6.06 \\
\hline \multicolumn{3}{|c|}{$\begin{array}{l}\text { Table-II. Age distribution of patients with bacterial } \\
\text { infection }(n=33)\end{array}$} \\
\hline Sex & $\begin{array}{l}\text { No. of Patients with } \\
\text { Bacterial Infection }\end{array}$ & Percentage (\%) \\
\hline Male & 21 & 63.64 \\
\hline Female & 12 & 36.36 \\
\hline \multicolumn{3}{|c|}{$\begin{array}{l}\text { Table-III. Gender distribution of patients with wheeze } \\
\text { in relation to bacterial infection }(n=33)\end{array}$} \\
\hline
\end{tabular}

Out of 130 patients presenting with wheeze, 50 (38.46\%) had temperature range of $98.1-99{ }^{\circ} \mathrm{F}$. Among them, 38 were male (76.0\%) and 12 were female patients (24.0\%). There were 32 (24.6\%) patients who had temperature range of 99.1$100{ }^{\circ} \mathrm{F}$, out of these, $22(68.8 \%)$ were male and $10(31.2 \%)$ female. There were $23(17.7 \%)$ patients who had temperature range of $100.1-101^{\circ} \mathrm{F}$, out of these, 15 (65.2\%) were male and 8 (34.8\%) female. A total of 16 (12.3\%) patients were having temperature range of $101.1-102{ }^{\circ} \mathrm{F}$, out of these, 11 (68.8\%) were male and 5 (31.2\%) female. Only nine patients were having temperature range of 102.1-103 ${ }^{\circ} \mathrm{F}, 6$ (66.7\%) were male and 3 (33.3\%) female.

Twelve (63.15\%) out of 19 patients under the age of 2 months had tachypnea i.e. respiratory rate $>60 /$ min. Total Patients between 2-12 months of age were 58, out of these, $32(55.18 \%)$ had tachypnea i.e. respiratory rate 50 or $>50 / \mathrm{min}$ whereas 53 patients were in the age range of 12-60 months, out of them, 21 (39.62\%) had respiratory rate 40 or above i.e. tachypnea.

Absolute neutrophil count was more than $5000 /$ dl in $42(32.30 \%)$ patients, out of these 33 (78.6\%) had bacterial infection according to criteria mentioned in operational definition, 9 patients did not fill the criteria for bacterial infection. 
Chest X-rays were showing infiltrates in 110 $(84.6 \%)$ patients. Among them, $68 \quad(61.8$ $\%)$ were having infiltrates on chest $x$ ray at the time of admission, remaining 42 (38.2\%) developed pulmonary infiltrates over next 3 days while 19 $(17.3 \%)$ had bilateral extensive infiltrates.

\section{DISCUSSION}

Wheezing in infants and toddlers is a common symptom, and these patients are difficult to approach both diagnostically and therapeutically. ${ }^{11}$ The most common cause for non-atopic wheezing is viral infection, most frequently caused by respiratory syncytial virus. ${ }^{12}$ But as we know, wheeze can be present along with bacterial etiologies as has been found by various researchers around the world.

Among 130 patient of this study, 33 (25.38\%) children were having bacterial infection, the highest frequency being documented in the age range of 1-12 months. Boys were affected more than girls which correlates with the study conducted in Japan by Nagayama.

Lethinen $\mathrm{P}$ et $\mathrm{al}^{13}$ conducted a study to determine bacterial co-infections in children with viral wheezing which showed serologic evidence of bacterial co-infection in $18 \%$ of the children, out of which only $10 \%$ were having pneumonia. Streptococcus pneumoniae (8\%) and Mycoplasma pneumoniae (5\%) were the most common causative bacteria.

Another study conducted by Mathews $B$ et $\mathrm{al}^{14}$ to confirm pneumonia radiographically in children presenting with wheeze, out of $47 \%$ wheezy children, $4.9 \%$ showed pneumonia on chest $x$-ray. It is not easy to differentiate viral etiologies from bacterial pneumonia with the help of chest radiographs. On the other hand, we also know that radiographically spotted pneumonia does not always guarantee bacterial etiologies. Streptococcus pneumonia is known to be one of the commonest pathogens involved in pneumonia while majority of the clinicians are advising antimicrobial drugs if the radiographic evidence is suggestive of pneumonia. Radiographic pneumonia along with high grade fever is considered to be one of the major predictors of pneumonia. Patients having temperature as more than or equal to $39.0^{\circ} \mathrm{C}$ have been observed to have 5 times more chance of having pneumonia in comparison to those with no fever. ${ }^{14}$ Among children aged more than 1 year, it was observed that $1^{\text {st }}$ wheezing episode along with tachypnea, tachycardia, fever and localized findings can identify around $95 \%$ of the pneumonia cases.

Nascimento-Carvalho CM demonstrated recently that there is a considerable overlap in clinical presentation of acute asthma and pneumonia. ${ }^{15}$ Recording of fever and chest in-drawing, and observing the response to bronchodilators, pneumonia can be reliably identified in children presenting with tachypnea and cough.

We have noted bacterial infection to be commonly associated with acute wheezing among children aged less than 5 years. It is suggested that bacterial, as well as viral infections may trigger an acute obstructive attack in children with reactive airways. The current Integrated management of childhood infections (IMCl) algorithm prescribes that children with wheeze and fast breathing presenting to first level health facilities are given antibiotics if they continue to have fast breathing after two doses of bronchodilator.

\section{CONCLUSION}

Although wheezing is commonly associated with viral respiratory tract infections but bacterial infection should also be suspected in children younger than 5 years with fever. Investigations should be performed especially chest x-ray and absolute neutrophil count in order to reduce the morbidity and mortality due to acute respiratory tract infection especially pneumonia.

\section{ACKNOWLEDGEMENT}

The authors would like to thank M. Aamir (Bahawalpur, Pakistan) for his volunteer assistance in statistical analysis of this research. Copyright $\odot 07$ Oct, 2020. 


\section{REFERENCES}

1. Al-Shamrani A, Bagais K, Alenazi A, Alqwaiee M, AlHarbi AS. Wheezing in children: Approaches to diagnosis and management. Int $\mathrm{J}$ Pediatr Adolesc Med. 2019; 6(2):68-73.

2. Martinez F.D., Wright A.L., Taussig L.M., Holberg C.J., Halonen M., Morgan W.J. Asthma and wheezing in the first six years of life. N Engl J Med. 1995; 332(3):133138.

3. Garcia-Marcos L., Mallol J., SoléD Brand PL., EISL Study Group International study of wheezing in infants: Risk factors in affluent and non-affluent countries during the first year of life. Pediatr Allergy Immunol. 2010; $21(5): 878$.

4. Mallol J., García-Marcos L., Solé D., Brand P., EISL Study Group International prevalence of recurrent wheezing during the first year of life: Variability, treatment patterns and use of health resources. Thorax. 2010; 65(11):1004-1009.

5. Guilbert T.W., Morgan W.J., Zeiger R.S., Bacharier L.B., Boehmer S.J., Krawiec M. Atopic characteristics of children with recurrent wheezing at high risk for the development of childhood asthma. J Allergy Clin Immunol. 2004; 114(6):1282-1287.

6. Tazinya AA, Halle-Ekane GE, Mbuagbaw LT, Abanda M, Atashili J, Obama MT. Risk factors for acute respiratory infections in children under five years attending the Bamenda Regional Hospital in Cameroon. BMC Pulm Med 2018; 18:7.

7. Arabi A, El Rassi R, El-Hajj FG. Hypovitaminosis D in developing countries-prevalence, risk factors and outcomes. Nat Rev Endocrinol. 2010; 6(10):550-61.
8. Hazir T, Qazi S, Nisar YB, Ansari S, Maqbool S, Randhawa $S$, et al. Assessment and management of children aged 1-59 months presenting with wheeze, fast breathing, and/or lower chest indrawing; Results of a multicentre descriptive study in Pakistan. Arch Dis Child. 2004; 89(11):1049-1054. doi:10.1136/ adc.2003.035741.

9. Strachan DP, Butland Bk, Anderson HR. Incidence and prognosis of asthma and wheezing illness from early childhood to age 33 in a national British cohort. $\mathrm{Br}$ Med J. 1996; 312:1195-99.

10. Stevens CA, Turner D, Kuehni Ce, Couriel JM, Silverman $M$. The economic impact of preschool asthma and wheeze. European Respiratory Journal 2003; 21(6):1000-6.

11. Rahman MA. Wheezing in pre school childrenapproach to diagnosis and management-review. ECPRM 2018; 7(6):424-45.

12. Papadopoulos NG, Kalobatsou A. Respiratory viruses in childhood asthma. Curr Opin Allergy Clin Immunol 2007; 7:91-5.

13. Lehtinen $P$, Jartti $T$, Virkki $R$, Vuorinen $T$, Leinonen $M$, Peltola $\mathrm{V}$, et al. Bacterial coinfections in children with viral wheezing. Eur J Clin Microbiol Infect Dis. 2006; 25(7):463-469.

14. Mathews $B$, Shah S, Cleveland $\mathrm{RH}$, Lee EY, Bachur RG, Neuman MI. Clinical predictors of pneumonia among children with wheezing. Pediatrics. 2009; 124(1):e29-e36.

15. Nascimento-Carvalho CM. Community-acquired pneumonia among children: the latest evidence for an updated management. J Pediatr (Rio J). 2020; 96(S1):29-38.

\begin{tabular}{|c|l|l|l|}
\hline \multicolumn{3}{|c|}{ AUTHORSHIP AND CONTRIBUTION DECLARATION } \\
\hline Sr. \# & \multicolumn{1}{|c|}{ Author(s) Full Name } & \multicolumn{1}{|c|}{ Contribution to the paper } & Author(s) Signature \\
\hline 1 & Maria Saleem & $\begin{array}{l}\text { Data collection, Data analysis, } \\
\text { Drafting. } \\
\text { Study concept, Supervision, } \\
\text { Proof reading. } \\
\text { Methodology, Literature review. }\end{array}$ \\
\hline 3 & Asim Khurshid & Waqas Imran Khan & Discussion, Data interpretation. \\
\hline 4 & Amna Wajdan & Amn \\
\hline
\end{tabular}

